\title{
The Likely Impact of COVID-19 on US Employment in the Medium Term
}

\author{
Lily Fu and Martin Schonger ${ }^{\#}$
}

${ }^{1}$ The Hockaday School, Dallas, TX, USA

\#Advisor

\section{$\underline{\text { ABSTRACT }}$}

COVID-19 caused an abrupt increase in unemployment rates for people across various fields of work. This paper compares the COVID-19 crisis with the Great Recession and the Spanish Influenza. After careful data collection and analysis, it is clear that COVID-19 caused a steep, immediate decline in the economy although it did not last long. By comparison, the Global Financial Crisis was a persistent recession though less severe. A comparison of the health effects for COVID-19 and the Spanish flu reveals that the influenza was much more contagious as it infected 29.3\% of the US population in three years. In contrast, this percent is $2.4 \%$ for COVID-19 as of August, 2021. The flu outbreak also coincided with WWI which caused further spread of the virus, and an effective vaccine was never developed. Therefore, the current economic decline should not be worse than that of the influenza. Moreover, the government is more actively participating in the economy now than it was during the flu pandemic. The Spanish flu had a V-shaped economic trend despite having minimal government involvement. Because the flu and coronavirus are both pandemic-induced crises, we would expect COVID-19 to be V-shaped as well, which is seen through the graphs below. U.S. data from the Federal Reserve is analyzed graphically in this paper, and it shows that the COVID19 crisis exhibits a distinct V-shape pattern. This suggests that economic recovery will be faster than the less severe Global Financial Crisis, and that countercyclical government policies may not be as necessary.

\section{Introduction}

The COVID-19 pandemic has placed several economic hardships on people. From the stock market crashing to job loss to fluctuating housing prices, this crisis has been almost unpredictable. This paper further dives into the question of how the coronavirus will affect employment rates in the future. First, some information about the current economic situation. Then, a comparison between COVID-19, the Global Financial Crisis (GFC), and the Spanish Influenza.

This paper specifically examines the economic trends during the GFC and COVID-19. Whereas the current situation creates a V-shape, the GFC forms a U-shape, suggesting that the economy will have a faster recovery during the pandemic. During the GFC, GDP fell by 631 billion over the course of a year. However, for the coronavirus, GDP fell by 1944 billion in just half a year. Therefore, the GFC had less severe economic impacts that lasted longer, and the COVID-19 crisis has harsher economic effects that are short-lived, causing a V-shape.

In comparison with the Spanish flu, COVID-19 is more deadly, but the flu is more contagious. However, the high COVID-19 death rate is largely due to the higher percentage of elderly people in our current population as opposed to the early 1900s. The GDP per capita during the coronavirus pandemic fell by $3.8 \%$, and it fell by $6 \%$ during the flu outbreak. 


\section{Literature Review}

In March 2020, many industries began to reduce their production of goods in response to the COVID-19 outbreak, and families were recommended to buy only necessary items. Together, this resulted in a decrease in employment rates and companies filing for bankruptcy. By April 2020, employment rates fell by 37\% for workers earning wages in the bottom quartile (Chetty et al., 2020). Coupled women were less likely to work than coupled men, and previously self-employed women may continue to stay out of the labor force as men are typically the breadwinner of the family (Kalenkoski and Pabilonia, 2020). As a result, this could have long-term harmful impacts on the female labor force, household income, and gender wage gap. Additionally, the youth have also been negatively affected by the virus. Not only have schools been shutting down, but entry-level jobs and internships are also becoming more scarce, causing high and persistent unemployment among youth (ILO-OECD, 2020). Furthermore, working hours have decreased by $14 \%$, and low-wage employees are twice more likely to have stopped working entirely (ILO-OECD, 2020).

\section{Three Crises: COVID-19, Global Financial Crisis, Spanish Influenza}

Although understanding the current situation and data is useful, it is equally important to make predictions about the outcome of this pandemic based on previous events. This paper compares the COVID-19 economic recession with the 2008 Financial Crisis and the 1918 Spanish Influenza Pandemic. Since the 2008 GFC is quite recent, aspects such as the government system and technology are very similar to today, which makes this event a good one for comparison. However, this crisis was caused by banks' mismanagement of loans, not a contagious disease. Therefore, comparison to the 1918 Spanish Influenza is also necessary because the circumstances in regard to physical well-being resembles the situation now.

\section{Global Financial Crisis}

The Global Financial Crisis of 2008 was a worldwide economic recession caused by insufficient financial regulation and banks taking too many risks. Several global financial institutions suffered, and some even went bankrupt. This financial crisis had similar effects as the current COVID-19 recession. Both caused lots of uncertainty and large drops in the stock market (Strauss-Khan, 2020). However, there are quite a few more differences. The COVID-19 recession affected supply first, then demand, whereas the 2008 global financial crisis (GFC) affected demand first (StraussKhan, 2020). When the coronavirus first hit in 2020, companies started to limit their production of goods since they wanted to slow the spread of the virus, creating disruptions in supply chains (Smith, 2020). In contrast, the GFC was caused by an increase in demand for mortgages.

To compare the economic impact of COVID-19 and the Global Financial Crisis, I examined the quarterly real U.S. GDP in trillions of dollars over time. After collecting and analyzing the data, I created the figures below to highlight the key difference. Figure 1 visualizes the data, which is taken from the U.S. Federal Reserve St. Louis (2021). Figures $1 \mathrm{a}$ and $1 \mathrm{~b}$ contain data nine quarters before the deepest point and six quarters after the deepest point. Figure 1a shows the GFC that formed a U-shape. The graph includes data from quarter one of 2007 to quarter four of 2010. The lowest real GDP during the GFC was 15.16 trillion in quarter two of 2009. GDP fell by 0.63 trillion over the course of a year, which is a $4 \%$ decline. Thus, this crisis was a long recession although less severe, creating a Ushape. Strauss-Khan also points out that the financial crisis had a U-shape since the recession had already slowly begun before 2008 and did not reach a rebound until the end of 2010 (2020). Therefore, the decline and recovery were long and drawn-out processes.

Figure $1 \mathrm{~b}$ depicts the COVID-19 recession, which shows a marked V-shape. The data starts from quarter one of 2018 and ends with quarter two of 2021 with forecasted data for quarter three and four of 2021. With this current pandemic, in a span of 15 months, everything shut down and mostly opened back up, creating a sharp V-shaped trend. 
During COVID-19, real GDP fell by 1.94 trillion in just half a year, which is a $10.1 \%$ decline. The lowest real GDP during the current pandemic was 17.26 trillion in quarter two of 2020.

In sum, the following comparison between the two crises emerges: (i) the GFC economic downturn exhibits a U-shaped pattern, but COVID-19 exhibits a V-shaped pattern, (ii) the fall in real GDP was more severe under COVID-19 with a decline of $10.1 \%$, whereas the decline for the GFC was $4 \%$, and (iii) the Great Recession persisted for almost three years, but the COVID-19 economic crisis lasted for less than a year and a half.

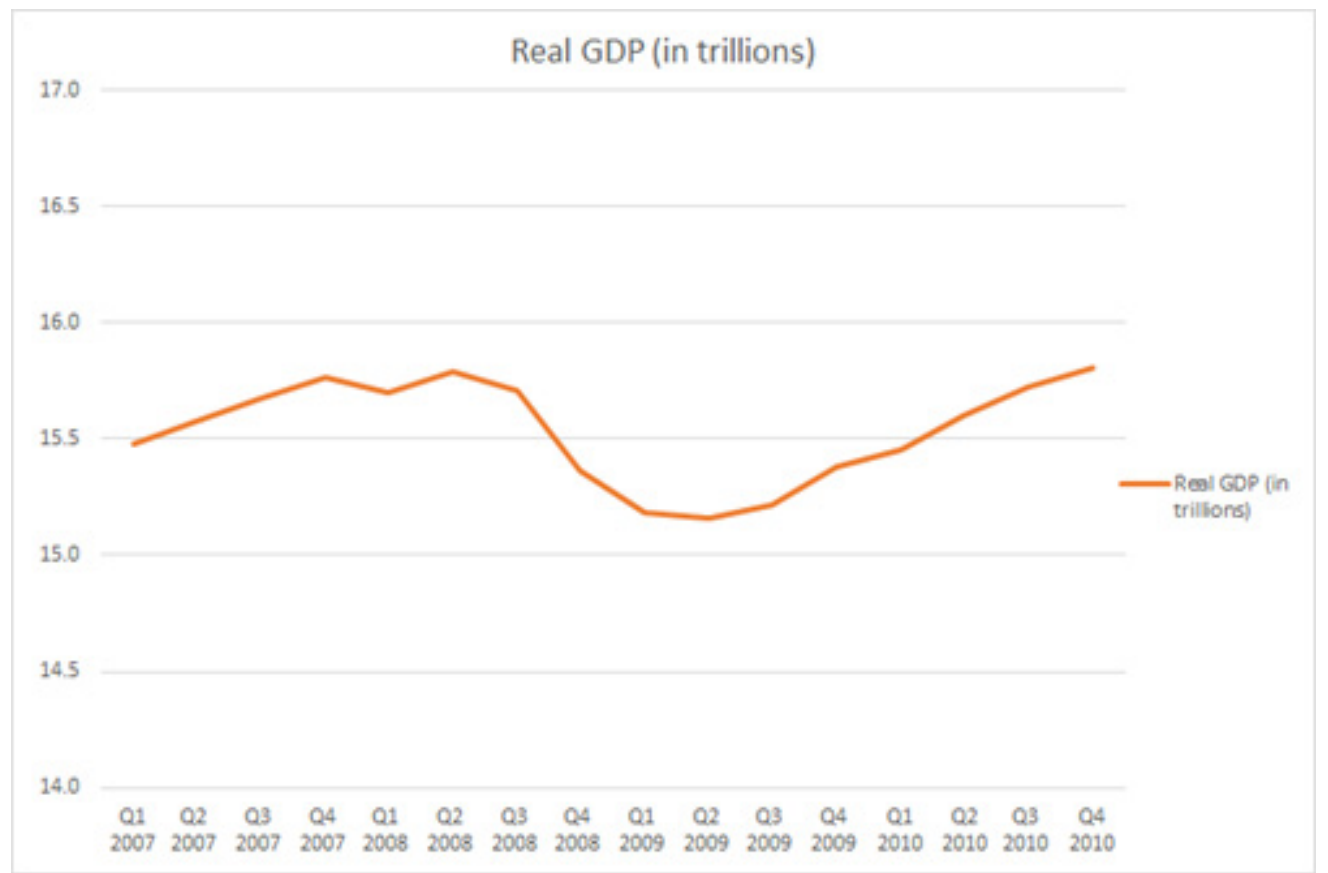

Figure 1a. Real GDP during the Global Financial Crisis

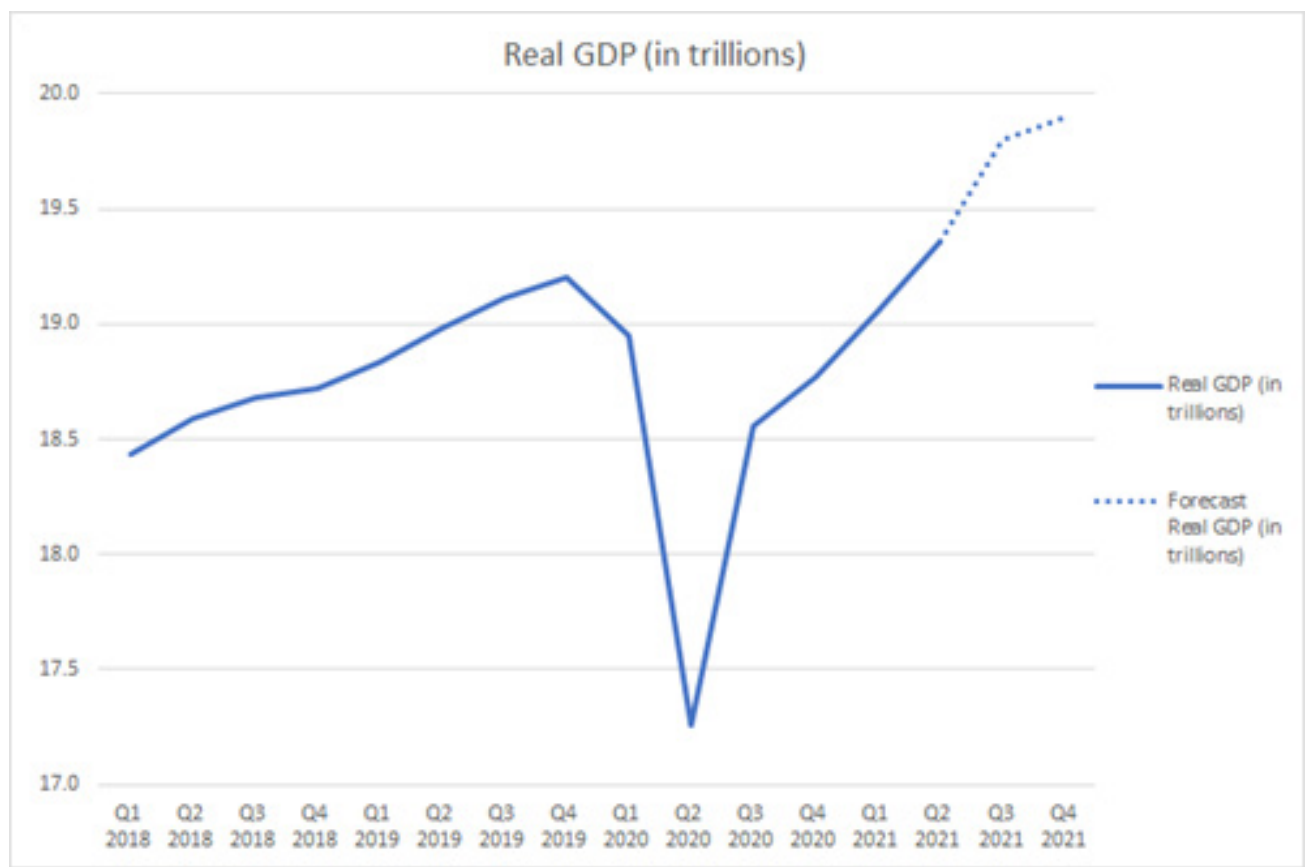

Figure 1b. Real GDP during the COVID-19 pandemic 
Figure 1 Note. Real GDP in trillions of dollars. Each figure shows nine quarters before the deepest point and six quarters after the deepest point.1a: 2008 Global Financial Crisis, lowest real GDP was 15.16 trillion in Q2 (Q2) of 2009. Q1 of 2007 to Q4 of 2010. 1b: COVID-19, lowest real GDP during COVID-19 was 17.26 trillion in Q2 of 2020. Q1 of 2018 to Q2 of 2021, forecast data for Q3 and Q4 of 2021. Data sources: U.S. Federal Reserve Bank of St. Louis (2021).

\section{Health Effects of COVID-19 and the Spanish Flu}

The Spanish Influenza was a highly deadly virus that spread across the globe rapidly. It lasted from 1918 to 1920, and the death toll worldwide was about 50 million (CDC, 2020). For the COVID-19 pandemic, the death toll is currently around 4 million globally (Worldometers, 2021).

Two key differences between the two crises are the infection rate and mortality rate of each. The infection rate for the Spanish Influenza was approximately $29.3 \%$ over its 3-year duration (Barro et al., 2020). For COVID-19, the rate is about $2.4 \%$ up to late June 2021 (WHO, 2021). The high infection rate of the Spanish flu prevented millions of employees from working. During the influenza, about $0.64 \%$ of the total population in the US died due to the flu (Ewing, 2021). However, with COVID-19, that rate is $0.15 \%$ up to May 2021 (Ewing, 2021). Because the death rate during COVID-19 is lower for the total population, this current crisis will likely have less severe economic complications than the Spanish Influenza. However, the death rate for infected people with the flu was about $0.022 \%$. For COVID-19, the mortality rate of infected individuals is about $0.0625 \%$ (WHO, 2021, Ewing, 2021). Although the Spanish flu had a higher death rate for the total population, COVID-19 has a higher death rate among infected people. This high mortality rate for individuals with the coronavirus is likely caused by the larger portion of middle aged and elderly people in the current US population as opposed to the 1910s and 1920s (Hobbs and Stoops, 2002). Therefore, the higher death rate for infected people is probably affecting people who are already out of the labor force.

With the advancement of current technology, virologists have developed vaccines that reduce transmission of the disease while preventing hospitalization if fallen ill. Because of modern medication, this has reduced the severity of the COVID-19 impact on the economy since it is returning back to almost "normal" after one year of social distancing. On the other hand, the Spanish Influenza lasted almost three years, making the economic damage worse. Furthermore, there was no effective vaccine available during the flu pandemic (Fornarola, 2021). In 1918, vaccines were developed by independent researchers and doctors who believed that the flu was a bacterium, not a virus, causing unsuccessful vaccines (Fornarola, 2021). But, with current technology, scientists have created effective vaccines against COVID-19, so this virus most likely will not remain here long enough for economic declines to occur in the long run. Additionally, WWI increased the spread of the Spanish flu since war created harsh conditions for the troops (Fornarola, 2021). Therefore, the COVID-19 crisis probably will not have worse economic complications than the ones during the flu outbreak due to the lack of a global war and development of successful vaccines.

Another important factor of each disease are the variants. For COVID-19, there currently are four different variants in the US: alpha, beta, gamma, and delta. They spread more quickly and easily than the first wave of COVID19, causing an increase in coronavirus cases (CDC, 2021). Similarly, the Spanish flu also had multiple variants. The first wave occurred simultaneously with WWI, which led to high infection rates due to the overcrowding of troops (CDC, 2018). The flu reached its peak during the second wave, which was the most fatal (CDC, 2018). The third wave was less severe, and it ended in 1920 (CDC, 2018). The Spanish flu had a higher infection rate not only because of WWI and lack of technology, but also because most people in the 1920s were not as financially stable as people right now. A century ago, people had to go to work just to make a living. In contrast, people nowadays tend to be wealthier, so more people are able to work from home and isolate themselves. A final key factor that differentiates the two crises is the current spending on health and safety. Because of the rapid spread of COVID-19, people are likely to spend more on healthcare in regard to the disease, especially if they become infected. This increased spending on COVID19 mitigation should reduce the severity of the disease and its economic impact. However, people are also going to 
spend less on travelling and eating out to lower the chance of catching the virus. This avoidance behavior will reduce economic activity, which would make the effect on the economy more severe. Therefore, health and safety concerns can both reduce and worsen the economic impact of COVID-19.

\section{Economic Effects of COVID-19 and the Spanish Flu}

While the Spanish Influenza and COVID-19 are similar since they both are contagious respiratory illnesses, the economies at the time were a bit different because the Spanish Influenza coincided with World War I (Maas, 2020). Participation in the war allowed the US to mobilize its economy. Mass producing war goods, the US added three million people to the military and half a million people to civilian government (Lozada, 2005). This caused unemployment to decline from $7.9 \%$ to $1.4 \%$ in 1918 (Lozada, 2005). However, after the war, unemployment rates rose to $11.7 \%$ in 1919 and 1920 (Ullman, 2020). Furthermore, the influenza reduced real per capita GDP by 6\% and real private consumption by $8 \%$ on average (Maas, 2020). By comparison, real GDP per capita in the US decreased drastically by $3.824 \%$ from 2019 to 2020; but this drop is about two-thirds of 6\% during the Spanish flu (World Bank, 2020). The total forecasted GDP loss due to the pandemic is estimated to be around $2.4 \%$ in the US (Szmigiera, 2021). Also, the current unemployment rate in the US is about $5.9 \%$ whereas the unemployment rate rose to $11.7 \%$ during the flu (Bureau of Labor Statistics, 2021). In comparison with the influenza, this COVID-19 statistic is about half of the flu. Although both pandemics heavily affected employment and GDP, they did so in different levels of severity with COVID-19 being less severe.

COVID-19 has affected most industries, especially the hospitality sector and the food service industry. When the virus first hit the US, many people abruptly stopped eating at restaurants and travelling, causing a huge decline in these sectors. In fact, in April 2020, employment in leisure and hospitality fell by 7.7 million, or 47\% (Bureau of Labor Statistics, 2020). Additionally, food and drinking services dropped by 5.5 million (Bureau of Labor Statistics, 2020). Also, employment declined in arts, recreation, and entertainment by 1.3 million (Bureau of Labor Statistics, 2020). Education and health services were negatively impacted, too, since schools were closing and lots of medical professionals were being exposed to COVID-19. Employment fell by 1.4 million in health care, and in education services, it declined by 2.5 million (Bureau of Labor Statistics, 2020). Furthermore, in April 2020, unemployment rates increased to $13 \%$ for men, $15.5 \%$ for women, $31.9 \%$ for teenagers, $14.2 \%$ for whites, $16.7 \%$ for blacks, $14.5 \%$ for Asians, and 18.9\% for Hispanics (Bureau of Labor Statistics, 2020). By contrast, in February 2020, the unemployment rates were $3.3 \%$ for adult men, $3.1 \%$ for adult women, $11.0 \%$ for teenagers, $3.1 \%$ for whites, $5.8 \%$ for blacks, $2.5 \%$ for Asians, and $4.4 \%$ for Hispanics (Bureau of Labor Statistics, 2020). Clearly, COVID-19 caused a severe, immediate recession for the US economy.

\section{Cause of V-Shape}

The economic trend for the Spanish flu was V-shaped despite the fact that the government hardly intervened. Since the flu pandemic coincided with WWI, the government had limited resources. Government spending was largely devoted to war efforts, so the government did not contribute to the development of the vaccine (Fornarola, 2021). However, the vaccine that was developed by independent doctors and researchers was ineffective (Fornarola, 2021). To make matters worse, the government prohibited the press and political leaders from discussing the flu in 1918 (Dayhoff, 2020). Because of the government's limited budget due to the war in 1918, it could not spend on materials like the vaccine, social welfare programs, and unemployment benefits. Therefore, the government did not assist much in the rebound of the economy. Despite all this, the flu recession was V-shaped and short-lived. Currently, with the coronavirus, the government is actively participating in the economy by spending money on stimulus checks and other benefits to mitigate the effects of the pandemic. Thus, the COVID-19 recession should not be worse than the Spanish influenza because the government is now involved in the economy, the coronavirus is less contagious than the flu, and 
medical professionals have developed an effective vaccine against COVID-19 whereas effective medication for the flu did not exist in the early 1900s.

Other factors that might cause a V-shape is simply the fact that the recession is pandemic induced. During recessions like the flu and COVID-19, most people who lose their jobs are only temporarily out of work, so they exit the labor force only for the duration of the pandemic, knowing that they will likely receive a similar job afterwards. However, recessions like the Global Financial Crisis are a much different case. Most layoffs during the GFC were permanent, making the economic trend more U-shaped and long-lasting. Therefore, the current recession is likely to be V-shaped and short-lived because of the nature of the recession: a pandemic induced crisis. Once enough people are vaccinated to reach herd immunity, more jobs will open back up. As the spread of the virus is being contained, the economy will return back to its full operating potential, and the employment rate will increase.

\section{Conclusion}

After examining the question of how COVID-19 will affect employment rates in the future, it is clear that the economic trend differs greatly from the GFC. While the GFC had a U-shaped curve, the COVID-19 pandemic data exhibits a $\mathrm{V}$-shaped curve. This is largely due to the fact that the impacts of the coronavirus are more short-term, unlike the GFC which were long-term.

Because COVID-19 and the flu are both respiratory illnesses that caused pandemics, a comparison with the Spanish flu is optimal. However, the flu is much more contagious than the coronavirus, so the current economic decline probably won't be as bad as the flu. Additionally, with modern technology, a vaccine against COVID-19 was developed in a year. This vaccine also protects against variants. During the early 1900s, there was no effective vaccine for the flu, so thousands of people were forced out of the workforce due to illness. Finally, the current government is heavily involved in the economy. It has provided stimulus checks and several relief programs to those most affected by COVID-19. These government contributions help drive the economy in the right direction. However, after WWI, the government was no longer spending millions of dollars on wartime efforts, which put restraints on the economy. A few weaknesses in this research include the comparisons made. The GFC was caused by poor banking choices whereas the COVID-19 recession was caused by a highly contagious disease. But, a comparison to the Spanish Influenza also has its limits since that simultaneously occurred during a global war. Therefore, future research must be conducted as the virus continues to fizzle out. Because there currently is no definite answer, predictions must continue to be adjusted as these events still unfold. In the future, researchers can use this paper as an experiment to better understand the impacts of a reduction in job market opportunities.

Additionally, this paper suggests that countercyclical policies may not be necessary. From the graphs provided, it is clear that COVID-19 had a deep V-shaped economic trend, and the lowest point was short-lived. This indicates that the government does not need to actively counter the economic decline during a pandemic induced crisis. Due to the nature of this crisis, it will not last long since modern medication and vaccines are rapidly improving the situation

This suggests that the U.S. government should focus on rapidly helping households in need, as well as R\&D in vaccines and an effective global vaccination campaign. Sustained fiscal stimulus is apparently not as necessary as one might think if compared to the Global Financial Crisis.

\section{Acknowledgments}

I would like to thank Dr. Schonger for advice and assisting me with editing. 


\section{References}

Barro, Robert J, Jose F. Ursua, and Joanna Weng. 2020. "The Coronavirus and the Great Influenza Pandemic: Lessons from the "Spanish Flu" for the Corornavirus's Potential Effects on Mortality and Economic Activity." NBER Working Paper Series No. 26866 (April). https://www.nber.org/system/files/working papers/w26866/w26866.pdf.

Bea. 2021. "Gross Domestic Product, 4th Quarter and Year 2020 (Advance Estimate)." Bea (January 28). Retrieved on August 15, 2021. https://www.bea.gov/news/2021/gross-domestic-product-4th-quarter-and-year-2020advance-estimate.

Bureau of Labor Statistics. 2020. "The Employment Situation - February 2020.” Bureau of Labor Statistics (March 6). Retrieved on August 15, 2021. https://www.bls.gov/news.release/archives/empsit 03062020.pdf.

Bureau of Labor Statistics. 2020. "Employment Situation News Release.” Bureau of Labor Statistics (May 8). Retrieved on August 15, 2021. https://www.bls.gov/news.release/archives/empsit 05082020.htm.

Bureau of Labor Statistics. 2021. "Employment Situation New Release." Bureau of Labor Statistics (June 4). Retrieved on August 15, 2021. https://www.bls.gov/news.release/archives/empsit 06042021.htm.

Bureau of Labor Statistics. 2021. "The Employment Situation - July 2021.” Bureau of Labor Statistics (August 6). Retrieved on August 15, 2021. https://www.bls.gov/news.release/pdf/empsit.pdf.

Centers for Disease Control and Prevention. 2018. "1918 Pandemic Influenza: Three Waves." Centers for Disease Control and Prevention (May 11). Retrieved on August 15, 2021. https://www.cdc.gov/flu/pandemicresources/1918-commemoration/three-waves.htm.

Centers for Disease Control and Prevention. 2019. "1918 Pandemic (H1N1 Virus)." Centers for Disease Control and Prevention (March 20). Retrieved on August 15, 2021. https://www.cdc.gov/flu/pandemicresources/1918-pandemic-h1n1.html.

Centers for Disease Control and Prevention. 2021. "What You Need to Know about Variants." Centers for Disease Control and Prevention (August 6). Retrieved on August 15, 2021. https://www.cdc.gov/coronavirus/2019ncov/variants/variant.html.

Chetty, Raj, John N. Friedman, Nathaniel Hendren, and Michael Stepner. 2020. "How did $\quad$ COVID-19 and Stabilization Policies Affect Spending and Employment? A New Real-Time Economic Tracker Based on Private Sector Data." NBER Working Paper Series No. 27431 (November). http://www.nber.org/papers/w27431.

Dayhoff, Kevin. 2020. "Dayhoff: Government Censorship Made the 1918 Spanish Flu Even Worse.” Carroll County Times (March 20). Retrieved on August 15, 2021. https://www.baltimoresun.com/maryland/carroll/lifestyles/cc-lt-dayhoff-032220-20200320wmahqlv3drbghpv2hziglq4jny-story.html.

Ewing, E. Thomas. 2021. "Measuring Mortality in the Pandemics of 1918-19 and 2020-21." Health Affairs (April 1). Retrieved on August 15, 2021. https://www.healthaffairs.org/do/10.1377/hblog20210329.51293/full/. 
Fornarola, Isaac. 2021. "What was Vermont's Vaccine Effort like during the 1918 Spanish Flu Outbreak?" Burlington Free Press (April 12). Retrieved on August 15, 2021. https://www.burlingtonfreepress.com/story/news/2021/04/12/covid-vaccine-comparing-vermonts-vaccineefforts-during-1918-spanish-flu-2021-2020/7188656002/.

Hobbs, Frank, and Nicole Stoops. 2002. "Demographic Trends in the 20th Century." US Census Bureau (November). Retrieved on August 15, 2021. https://www.census.gov/prod/2002pubs/censr-4.pdf.

International Labour Organization - Organization for Economic Cooperation and Development. 2020. "The Impact of the COVID-19 Pandemic on Jobs and Incomes in G20 Economies." Organization for Economic Cooperation and Development Paper. https://www.ilo.org/wcmsp5/groups/public/---dgreports/--cabinet/documents/publication/wcms 756331.pdf.

Kalenkoski, Charlene Marie, and Sabrina Wulff Pabilonia. 2020. "Initial Impact of the COVID-19 Pandemic on the Employment and Hours of Self-Employed Coupled and Single Workers by Gender and Parental Status." IZA Discussion Paper No. 13443 (July). http://ftp.iza.org/dp13443.pdf.

Lozada, Carlos. 2005. “The Economics of World War I.” NBER (January). Retrieved on August 15, 2021. https://www.nber.org/digest/jan05/economics-world-war-i.

Maas, Steve. 2020. "Social and Economic Impacts of the 1918 Influenza Epidemic." NBER (May). Retrieved on August 15, 2021. https://www.nber.org/digest/may20/social-and-economic-impacts-1918-influenzaepidemic.

Moreira, Ana Luisa. 2021. "How the COVID-19 Crisis Differs from the Economic Crises in the Past?" PQE Group. Retrieved on August 15, 2021. https://www.pqegroup.com/blog/2020/10/how-the-covid-19-crisis-differsfrom-the-economic-crises-in-the-past/.

Osterland, Andrew. 2020. "Here are Key Ways the Coronavirus Crisis Differs from the Great Recession." CNBC (May 27). Retrieved on August 15, 2021. https://www.cnbc.com/2020/05/27/here-are-key-wayscoronavirus-crisis-differs-from-the-great-recession.html.

Peter G. Peterson Foundation. 2021. "What to Know About All Three Rounds of Coronavirus Stimulus Checks." Peter G. Peterson Foundation (March 15). Retrieved on August 15, 2021. https://www.pgpf.org/blog/2021/03/what-to-know-about-all-three-rounds-of-coronavirus-stimulus-checks.

Peter G. Peterson Foundation. 2021. "How Did Americans Spend Their Stimulus Checks and How Did It Affect the Economy?" Peter G. Peterson Foundation (May 14). Retrieved on August 15, 2021. https://www.pgpf.org/blog/2021/05/how-did-americans-spend-their-stimulus-checks-and-how-did-it-affectthe-economy.

Rockoff, Hugh. 2008. "US Economy in World War I.” EH.Net Encyclopedia, edited by Robert Whaples (February 10). Retrieved on August 15, 2021. https://eh.net/encyclopedia/u-s-economy-in-world-war-i/. 
Smith, Christine. 2020. "Understanding Supply and Demand Shocks amid Coronavirus." Federal Reserve Bank of St. Louis (March 25). Retrieved on August 15, 2021. https://www.stlouisfed.org/openvault/2020/march/supply-demand-shocks-coronavirus.

Strauss-Kahn, Marc-Olivier. 2020. "Can We Compare the COVID-19 and 2008 Crises?” Atlantic Council (May 5). Retrieved on August 9, 2021. https:/www.atlanticcouncil.org/blogs/new-atlanticist/can-we-compare-thecovid-19-and-2008-crises/.

Szmigiera, M. 2021. "Statistics and Facts on the Impact of the Coronavirus Pandemic on the Global Economy." Statista (August 3). Retrieved on August 15, 2021. https://www.statista.com/topics/6139/covid-19-impacton-the-global-economy/\#topicHeader wrapper.

The World Bank. 2020. “GDP Per Capita Growth (Annual \%) - United States.” The World Bank. Retrieved on August 15, 2021. https://data.worldbank.org/indicator/NY.GDP.PCAP.KD.ZG?locations=US.

Ullman, Harlan. 2020. "Economic Recovery from Coronavirus: Lessons from 1918-1923." Atlantic Council (May 1). Retrieved on August 15, 2021. https://www.atlanticcouncil.org/blogs/new-atlanticist/economicrecovery-from-coronavirus-lessons-from-1918-1923/.

U.S. Federal Reserve Bank of St. Louis. 2021. "Real Potential Gross Domestic Product.” Federal Reserve Bank of St. Louis (July 1). Retrieved on August 15, 2021. https://fred.stlouisfed.org/series/GDPPOT.

U.S. Federal Reserve Bank of St. Louis. 2021. "Real Gross Domestic Product.” Federal Reserve Bank of St. Louis (July 29). Retrieved on August 15, 2021. https://fred.stlouisfed.org/series/GDPC1.

Worldometer. 2021. “Coronavirus Death Toll.” Worldometer (August 15). Retrieved on August 15, 2021. https://www.worldometers.info/coronavirus/coronavirus-death-toll/.

World Health Organization. 2021. "WHO Coronavirus (COVID-19) Dashboard.” World Health Organization (August 13). Retrieved on August 15, 2021. https://covid19.who.int/. 